\title{
PROJEKTIRANJE SILOSA S ASPEKTA NAČINA PROTOKA MATERIJALA PRI PRAŽNJENJU
}

\author{
Davor Skejić \\ Sveučilište u Zagrebu, Građevinski fakultet, docent \\ Marina Bolanča \\ Sveučilište u Zagrebu, Građevinski fakultet, student
}

Sažetak: U ovome članku obrađena je problematika pražnjenja materijala kod cilindričnog konusnog čeličnog silosa. Budući da je postupak pražnjenja silosa jedan od najkritičnijih slučajeva opterećenja, potrebno ga je detaljno razmotriti prilikom projektiranja. Pri pražnjenju silosa može doći do nekoliko načina protoka materijala. Zbog činjenice da svaki način protoka rezultira bitno različitim pritiscima na stijenke silosa, nužna je, s ekonomskog i sigurnosnog aspekta, pouzdana procjena procesa pražnjenja. Ovisno o namjeni silosa i svojstvima uskladištenog materijala, potrebno je ciljano projektirati kako bi se postigao poželjni način pražnjenja. Zaključno, ovaj rad kroz numeričku analizu prikazuje kako male promjene u geometriji konstrukcije silosa mogu uzrokovati različite načine pražnjenja.

Ključne riječi: projektiranje, silos, pražnjenje, način protoka materijala

\section{DESIGN OF SILOSFROM THE ASPECT OF FLOW MODE DURING DISCHARGE}

\begin{abstract}
This article deals with the material flow problems of a cylindrical conical steel silos during discharge. Since the silos discharge process belongs to one of the most critical load cases, it is necessary to be accounted for during design. During the silos discharge the several modes of material flow can occur. Due to fact that each of the flow modes result in significantly different pressures on the silos walls, from the safety and economical aspect, it is required to have reliable assessment of the discharge process. Depending on the silos purpose and stored material properties it is necessary to design with aim to achieve the desired discharging mode. In conclusion, the present work, through the numerical analysis, gave insights into how the small variations in the silos structural geometry can cause different discharging modes.
\end{abstract}

Key words: design, silos, discharging process, modes of the material flow 


\section{Općenito o projektiranju silosa}

Projektiranje silosa jedan je od najvećih izazova za projektante, jer složeno ponašanje silosa može biti izuzetno teško predvidljivo s obzirom na geometriju, uvjete oslanjanja i svojstva uskladištenog materijala. Projektirati skladišnu ćeliju ne znači samo proračunati dimenzije konstrukcijskih elemenata, nego i proučiti geometrijske oblike objekta, položaj i veličinu ispusnog otvora s opremom za punjenje i pražnjenje skladišnog prostora. Potrebno je adekvatno procijeniti statički pritisak i pritisak zbog protjecanja materijala tijekom pražnjenja, te dinamičke efekte. Nejednolika djelovanja, toplinske utjecaje i utjecaje zbog nestandardne tvorničke proizvodnje također treba uzeti u obzir. Problem nesmetanog pražnjenja skladišnih ćelija nije točno riješen, a može se najuspješnije riješiti propisanim ispitivanjima uz velike financijske izdatke.

Problematika projektiranja silosa obuhvaćena je u EN 1991-4 [1], EN 1993-4-1 [2] i EN 1993-1-6 [3]. EN 1991-4 [1], daje projektantu pojednostavljenja koja omogućuju uzimanje u obzir inače komplicirane slučajeve opterećenja i ponašanja silosa, kao što su nesimetričnost pri punjenju i pražnjenju, te u zamjenu za potrebna ispitivanja daje gotove parametre materijala. Danas europske norme donose podjelu silosa prema načinu proračuna vertikalnih zidova silosa, pri čemu se uvodi pojam „vitkost silosa“ (odnos visine ćelije i promjera upisanog kruga baze ćelije). Klase silosa prema vitkosti i prema postupku proračuna su [1]:

- silosi velike vitkosti

- silosi srednje vitkosti

- zdepasti silosi

- vrlo zdepasti silosi s ravnim dnom.

Na osnovi navedene podjele provodi se i vrjednovanje djelovanja na silos te konstrukcijski proračun silosa. Jedan od najkritičnijih slučajeva opterećenja (djelovanja) na silos je opterećenje pri pražnjenju silosa. Način proračuna i uzimanja u obzir opterećenja pražnjenja uvelike ovisi o načinu protoka uskladištenog materijala koji se pojavljuje tijekom pražnjenja. Potrebno je iskustvo i velika pažnja da bi se točno odredio način protoka koji ovisi o velikom broju parametara, uključujući svojstva uskladištenog materijala, geometrijske postavke i konstrukcijsko projektiranje.

Poznavanje mehaničkih svojstava rasutih tvari je bitno jer svojstva trenja i kohezije variraju s obzirom na vrstu uskladištenog materijala. Ta svojstva značajno utječu na ponašanje materijala. Dodatno, svojstva protoka mogu značajno varirati s promjenama velikog broja parametara, uključujući veličinu čestica, vlagu, temperaturu i konsolidacijske pritiske. Promjenjivost ovih parametara ukazuje na činjenicu da je ispitivanje stvarnih svojstava uskladištenog materijala veoma važno.

Uzimajući u obzir projektiranje geometrije silosa, potencijalni problemi uključuju stvaranje svoda (tzv. zasvođavanje, eng. arching) preko otvora ispusta, formiranje cjevaste rupe kroz materijal (eng. ratholing/piping) i sam način protoka tijekom pražnjenja. Sklonost rasutog materijala zasvođavanju ili formiranju cjevaste rupe je prvenstveno povezano s njegovom kohezivnošću, dok način protoka tijekom pražnjenja ovisi o kutu unutarnjeg trenja materijala i trenju koje se pojavljuje između materijala i stijenki silosa. Cilj projektiranja geometrije silosa je postizanje optimuma između iskoristivosti kapaciteta silosa i ukupnih troškova izgradnje.

Konstrukcijsko projektiranje silosa, [4], uključuje odabir optimalnog kuta lijevka i minimalne dimenzije ispusta. Upravo toj problematici, uz razmatranje načina protoka pri pražnjenju i posljedičnih pritisaka na stijenke silosa, posvećen je ovaj rad. Navedena tematika je obrađena preko teorijskog razmatranja do tipičnog primjera projektiranja silosa koji je detaljno analiziran u okviru diplomskog rada kolegice Bolanča [5].

\section{Načini protoka sipke tvari pri pražnjenju silosa}

\subsection{Općenito}

Kod projektiranja silosa neophodno je proanalizirati različite omjere dimenzija silosa (vitkosti), geometrijske oblike lijevka i postupke pražnjenja, jer sve navedeno uvelike utječe na proračunske situacije koje se moraju razmotriti. Pritom je potrebno analizirati načine protoka materijala tijekom pražnjenja, a koji se mogu kategorizirati kako slijedi:

- masovni protok 
- dimnjački protok $\rightarrow$ a) cjevasti protok

- prošireni protok

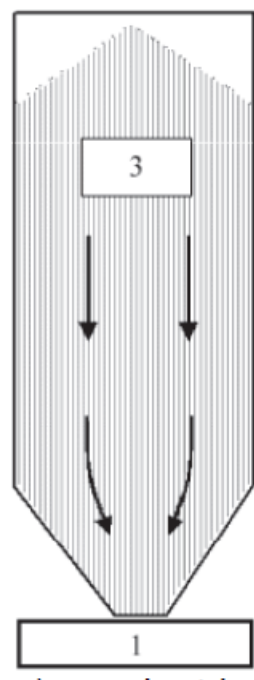

a) masovni protok

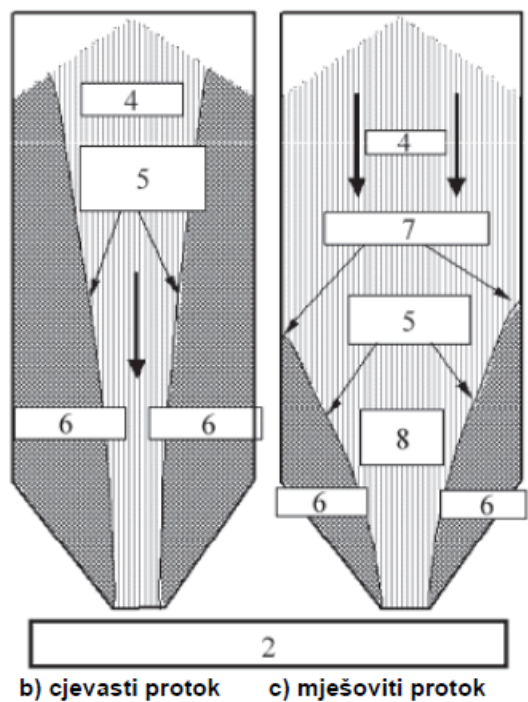

Legenda:

1 masovni protok

2 dimnjački protok

3 sva sipka tvar u kretanju

4 protok

5 granica protočnog kanala

6 nepomično

7 efektivni prijenos

8 efektivni lijevak

\section{Slika 1 - Osnovni načini protoka [1]}

U slučaju masovnog protoka, cijeli sadržaj silosa je u pokretu tijekom pražnjenja, slika 1.a). Masovni protok je moguć jedino u slučaju strmih i glatkih stijenki lijevka i ako se materijal prazni kroz cijeli otvor ispusta.

Ako su stijenke lijevka plitke (ravne) i hrapave, pojavit će se dimnjački protok, slike 1.b) i 1.c). U slučaju dimnjačkog protoka, u pokretu je jedino dio materijala koji se nalazi u području iznad ili u okolini ispusta. Materijal uz stijenke silosa miruje i naziva se 'mrtva' ili nepomična zona. Taj se dio materijala može isprazniti jedino kada je silos ispražnjen i to se radi najčešće mehanički. Granica protočnog kanala može sjeći površinu stijenke tijekom punjenja, tako da je moguće vidjeti dimnjački protok promatrajući s vrha silosa. Međutim, moguće je i da se granica protočnog kanala pojavi niže, tako da dimnjački protok nije moguće zamijetiti.

Uz način protoka, od iznimne je važnosti procijeniti je li protok centričan ili postoji ekscentricitet prilikom pražnjenja silosa. Procjena učinaka ekscentričnog pražnjenja u odnosu na procjenu učinaka centričnog pražnjenja izuzetno je složena [6] i [7], ali se ovdje zbog opsežnosti neće obrazlagati. Grafički prikaz načina cjevastog protoka i mješovitog protoka dan je u EN 1991-4 [1].

\section{Masovni protok}

\subsection{Općenito o masovnom protoku}

Kako je već rečeno, pri masovnom protoku cijeli sadržaj silosa je u pokretu tijekom pražnjenja te je omogućeno potpuno pražnjenje silosa, slika 2.a). Masovni protok predstavlja neke očite prednosti, a jedna od bitnijih je da je zagarantirano kompletno pražnjenje sadržaja silosa. Kada je ispravno projektirano, masovni protok može ponovno promiješati sipke tvari koje su se možda segregirale tijekom punjenja silosa. Iz toga se razloga preporuča za skladištenje ugljena i ostalih materijala sklonih segregaciji [8].

Pri masovnom istjecanju, materijal koji je prvi unutra pri punjenju, prvi je vani pri pražnjenju (eng. first-in, first-out mod). To svojstvo je bitno kod materijala poput ugljena, kada je bitno da se materijal nastavi gibati po visini silosa da bi se smanjio rizik spontanog izgaranja. Masovni protok omogućuje materijalu da se giba po visini silosa bez nastajanja kanala. To onemogućuje stagniranje i efekt segregacije materijala u silosu. U masovnom protoku može također doći do zastoja protoka ako se stvori svod nad otvorom ispusta. To se događa ako je otvor 
premalen u odnosu na veličinu čestica materijala (zasvođavanje koje uzrokuje blokiranje protoka). Masovni protok može uzrokovati vibracije silosa tijekom pražnjenja, koje mogu biti izrazito opasne.

Kut konusnog dijela od horizontale, slika 2., je između $68^{\circ}-72^{\circ}$, ovisno o uskladištenom materijalu. Otvor ispusta mora biti odgovarajuće veličine da spriječi formiranje svoda, ali i da omogući zahtijevanu stopu protoka, slika 2.b) [8].

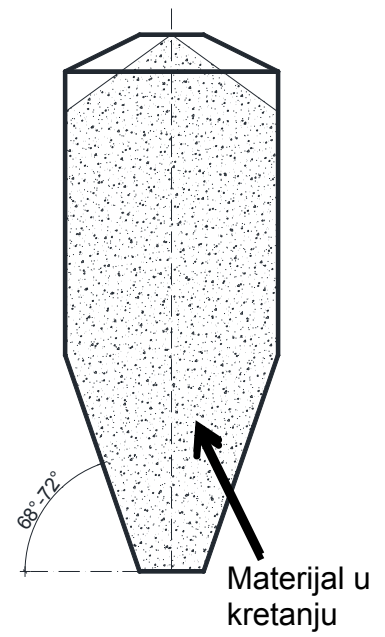

a) Tijekom punjenja

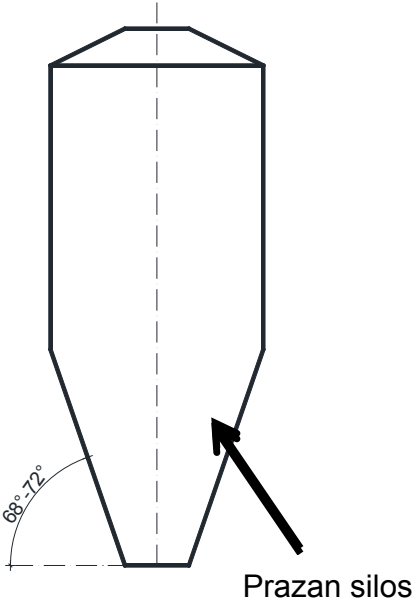

b) Nakon pražnjenja
Prednosti masovnog protoka, [9]:

- protok je dosljedniji, jednolik

- lakše je predvidjeti polje naprezanja

- iskorišten je cijeli skladišni kapacitet silosa

- nema pojave formiranja cjevaste rupe unutar materijala (eng. ratholing)

- nema zaostajanja materijala

- prvi-unutra, prvi-van redoslijed pražnjenja

- reduciran efekt radijalne segregacije.

Nedostatci masovnog protoka, [9]:

- habanje stijenki (abrazija)

- veći pritisci na stijenke silosa

- veća zahtijevana visina silosa.

\section{Slika 2 - Masovni protok materijala}

\subsection{Pritisci na stijenke silosa pri masovnom protoku}

Na početku procesa pražnjenja lijevka masovnim protokom, sve čestice su u pokretu te se uvjeti naprezanja u lijevku mijenjaju. Počevši od teorijskog vrška lijevka, prevladava pasivno stanje (polje) naprezanja. Kada sipka tvar teče kroz konvergirajući lijevak, pritisnuta je horizontalno, dok se vertikalno naprezanje smanjuje zbog protoka prema dolje. Dakle, naprezanja koja djeluju u horizontalnom smjeru postaju veća (veliko glavno naprezanje djeluje horizontalno u osi lijevka). U vertikalnom dijelu silosa aktivno stanje naprezanja ostaje nepromijenjeno ako nisu prisutne lokalne konvergencije (zbog udubljenja, umetaka i slično). Na prijelazu iz aktivnog u pasivno polje naprezanja (prijelaz iz cilindričnog u konusni dio silosa s masovnim protokom) pojavljuje se lokalni vršak (šiljak) u dijagramu naprezanja, slika 3. Pasivno stanje naprezanja ostaje i ako je pražnjenje zaustavljeno.

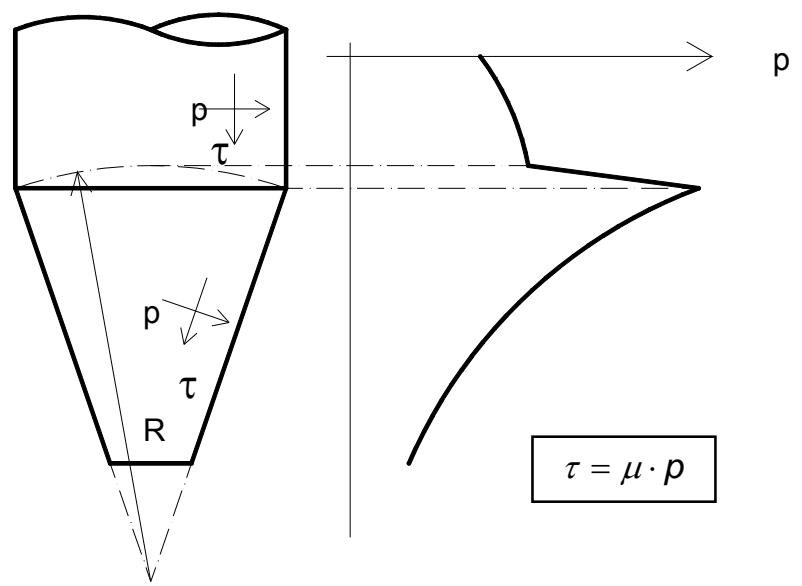

$\tau$-tangencijalni pritisak na stijenku

$\mu$-koeficijent trenja

$\mathrm{p}$-normalni pritisak na stijenku

Slika 3 - Distribucija normalnog i tangencijalnog pritiska pri masovnom protoku kod pražnjenja [10] 


\section{Dimnjački protok}

\subsection{Općenito o dimnjačkom protoku}

Silosi s dimnjačkim protokom uobičajeno imaju zdepaste lijevke ili ravno dno, te skladište više materijala nego silosi s masovnim protokom iste ukupne visine i promjera. Prednosti manjeg ispusta i reduciranog ukupnog troška čine dimnjački protok atraktivnim rješenjem u određenim prilikama, npr. kada segregacija materijala ne predstavlja problem. Presudno je pri projektiranju silosa s dimnjačkim protokom izbjeći nepravilan protok, formiranje cjevaste rupe (eng. ratholing) i osigurati potpuno istjecanje materijala tijekom pražnjenja.

Silosi s dimnjačkim protokom koriste se za skladištenje zrnastijh materijala, gdje nema problema $\mathrm{s}$ propadanjem materijala. Način pražnjenja je takav da materijal koji je prvi unutra pri punjenju, zadnji ide van pri pražnjenju. Tijekom pražnjenja stvara se kanal u sredini te taj materijal prvi teče, slika 4.a), a okolni materijal se slijeva u kanal postepeno kako se silos prazni. Dio materijala koji ostaje uz stijenke silosa naziva se 'mrtva' ili nepomična zona, slika 4.b). Kut lijevka od horizontale za dimnjački protok se kreće od $45^{\circ}-60^{\circ}$. Silosi s dimnjačkim protokom su općenito $20-30 \%$ jeftiniji od onih s masovnim protokom [8].

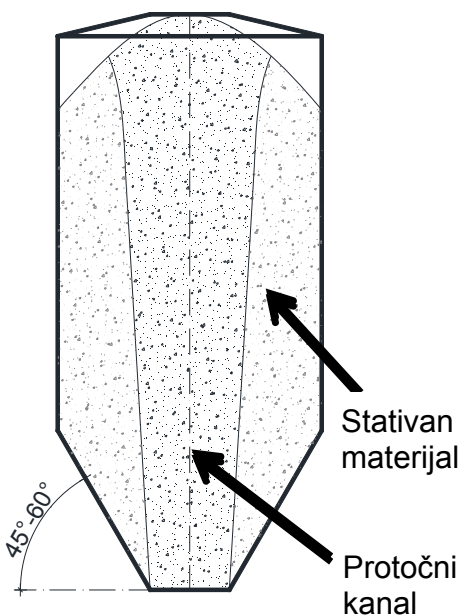

a) Tijekom punjenja

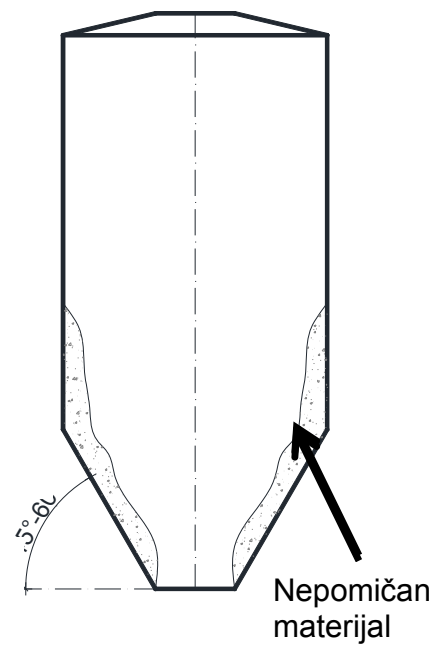

b) Nakon pražnjenja
Prednosti, [9]:

- manja visina silosa.

Nedostatci, [9]:

- formiranje cjevaste rupe, ako je materijal kohezivan

- stvrdnjavanje i kvarenje materijala

- poplavljivanje praškastih tvari

- prvi-unutra, zadnji-van redoslijed pražnjenja

- segregacija

- vremenska konsolidacija

- kolaps silosa

- ograničen skladišni kapacitet silosa.

\section{Slika 4 - Dimnjački protok materijala}

\subsection{Pritisci na stijenke silosa pri dimnjačkom protoku}

Budući da nema protoka materijala uzduž stijenki lijevka (osim možda pri pražnjenju silosa na samom kraju procesa), razumno je u većini slučajeva razmotriti da su normalni pritisci na stijenke lijevka jednaki onima koji se pojavljuju tijekom punjenja silosa. To podrazumijeva da nije potreban dodatan proračun za lijevak silosa. Pretpostavka vrijedi ako su zadovoljeni uvjeti da nema pojave stvaranja stabilnog svoda ili cjevaste rupe tijekom pražnjenja. Također je bitno da nema samoizazvanih vibracija silosa koje mogu utjecati na vrijednosti pritisaka, a koje nastaju urušavanjem prvotno neaktiviranog materijala tijekom pražnjenja.

Što se tiče cilindričnog dijela silosa, potrebno je razmotriti dva glavna slučaja. Prvo, ako protočni kanal ne dodiruje stijenku cilindra, sigurno je i razumljivo pretpostaviti da su pritisci na stijenku jednaki onima koji nastaju tijekom početnog punjenja.S druge strane, ako protočni kanal dodiruje stijenke cilindra, potrebno je razmotriti je li protočni kanal centriran (dodiruje li stijenku cilindra na istoj razini po opsegu). Na mjestu prijelaza, gdje protočni kanal dodiruje stijenku, dolazi do brzog porasta pritisaka na stijenku. Unutar samog protočnog kanala, razumljivo je pretpostaviti da će pritisci varirati kao u slučaju masovnog protoka, ali s kutom lijevka zamijenjenim s kutom protočnog kanala i s kutom trenja stijenke zamijenjenim s kutom unutarnjeg trenja materijala. 
Uobičajeno se usvaja konzervativna pretpostavka da su normalni pritisci na stijenke cilindra jednaki normalnim pritiscima na protočni kanal [10].

Važno je znati točan položaj gdje protočni kanal dodiruje stijenku, jer se na tome mjestu pojavljuje 'šiljak' u dijagramu pritisaka [11], kao i pri uvjetima masovnog protoka na mjestu prijelaza cilindričnog dijela silosa u konusni, slika 5. Carson i Jenkyn [10], preporučuju da se ukupna radijalna sila koja izaziva vršni pritisak, pomnožena efektivnom površinom na koju djeluje, zamijeni manjim jednolikim pritiskom raspodijeljenim na odgovarajuću visinu stijenke.

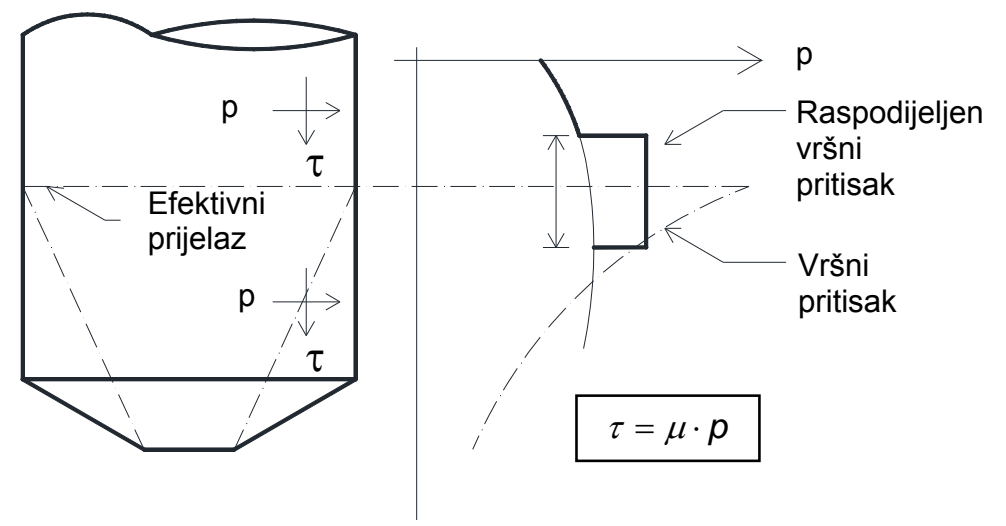

$\tau$ - tangencijalni pritisak na stijenku

$\mu$-koeficijent trenja

$\mathrm{p}$ - normalni pritisak na stijenku

\section{Slika 5 - Lijevak s dimnjačkim protokom (protočni kanal dodiruje stijenke cilindra) [10]}

Ako protočni kanal nije simetričan, ali i dalje dodiruje jednu ili sve stijenke cilindra, uvjeti opterećenja postaju mnogo kompliciraniji. Ekscentrični protočni kanal može izazvati nejednolike pritiske koji djeluju na stijenke silosa [7]. Dodatno, postoji veliki broj zabilježenih slučajeva oštećenih ili srušenih čeličnih silosa zbog pojave ekscentričnih protočnih kanala [12].

\subsection{Prošireni protok}

Prošireni protok materijala iz silosa je protok kod kojega donji dio lijevka silosa ima stijenke koje su dovoljno strme i dovoljno glatke da se na njma javlja protok, dok su stijenke u gornjem dijelu lijevka ili preblage ili prehrapave za javljanje protoka. Pod pretpostavkom da se protočni kanal u donjem dijelu lijevka širi dovoljno da spriječi formiranje cjevaste rupe na vrhu ovog dijela (odnosno, promjer protočnog kanala premašuje kritični promjer materijala za formiranje cjevaste rupe), u silosu se neće pojaviti cjevasta rupa.

Ako je utvrđeno da je ispust dovoljno velik da ne dođe do pojave zasvođavanja i samoizazvanih vibracija tijekom pražnjenja, može se zaključiti da su u cilindričnom dijelu silosa i u gornjem dijelu lijevka gdje nema protoka uzduž stijenki lijevka, opterećenja jednaka onima nastalima zbog dimnjačkog protoka. Nadalje, donji dio lijevka, gdje postoji protok uzduž stijenki lijevka, može biti projektiran kao u slučaju lijevka s masovnim protokom.

Prošireni protok se razvija kada je lijevak s masovnim protokom smješten ispod lijevka s dimnjačkim protokom, slika 6 . Lijevak s masovnim protokom se projektira radi aktiviranja dovoljno velikog protočnog kanala $u$ lijevku s dimnjačkim protokom, bez formiranja cjevaste rupe. Ovaj način protoka može biti djelotvoran za silose velikog promjera. 


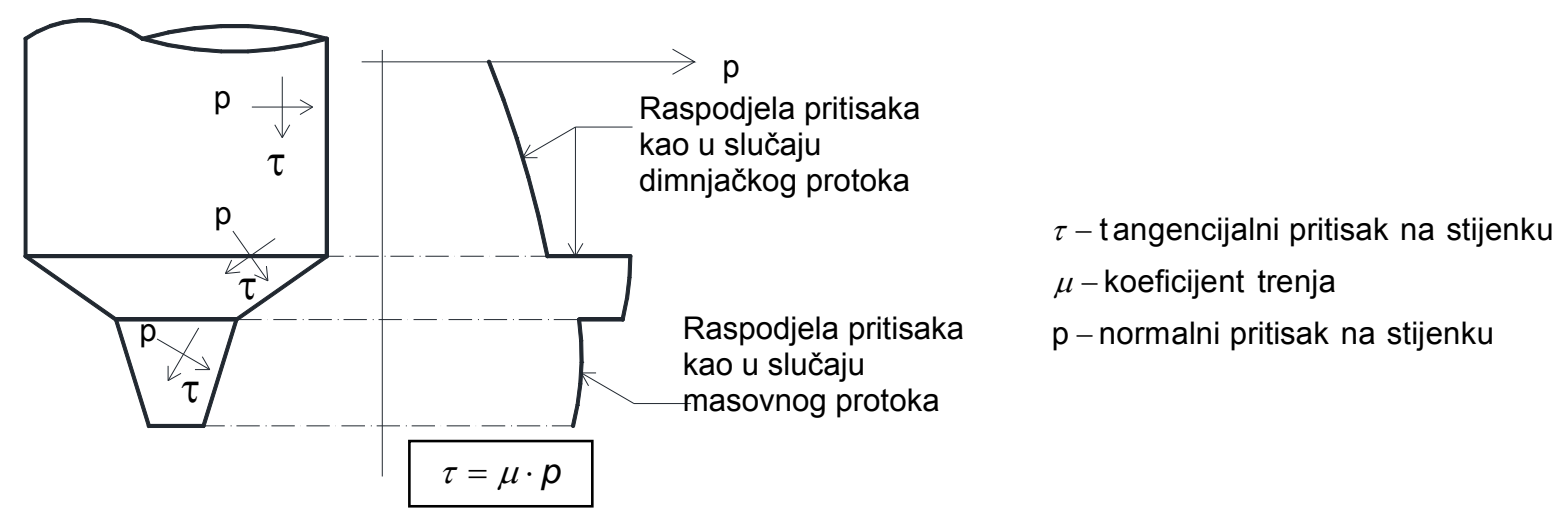

Slika 6 - Silos s proširenim protokom [10]

\section{$5 \quad$ Nepravilni protoci}

Dva glavna problema protoka do kojih može doći u silosu ili lijevku su zasvođavanje (eng. arching) i formiranje cjevaste rupe (eng. ratholing), slika 7. Zasvođavanje se pojavljuje kada se iznad otvora lijevka formira prepreka u obliku svoda i zaustavi protok. To može biti utoreni svod, gdje se velike čestice mehanički spajaju tvoreći formu prepreke ili kohezivnog svoda, slika 7.a). Kohezivni svod nastaje kada se čestice spoje zbog efekta vlage, koncentracije finih čestica, oblika čestica, temperature, itd. Zasvođavanje se može spriječiti dobrim kliznim svojstvima obloge stijenke i dovoljno velikim otvorom ispusta.

Formiranje cjevaste rupe nastaje jedino u slučaju pražnjenja kroz protočni kanal koji je smješten iznad otvora ispusta. Ako je uskladišteni materijal kohezivan, materijal izvan protočnog kanala neće protjecati te se može stvrdnuti ili pak samo nakupljati. Kada se protočni kanal isprazni, zaustavi se sav protok materijala, slika 7.b).

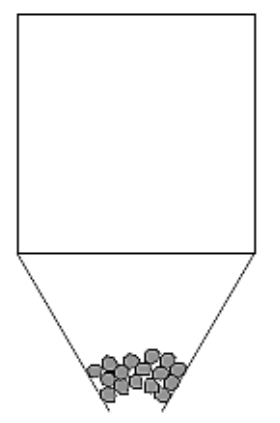

a) Zasvođavanje

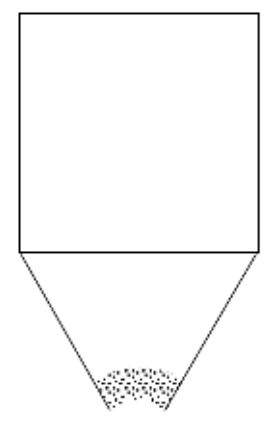

b) Cjevasta rupa

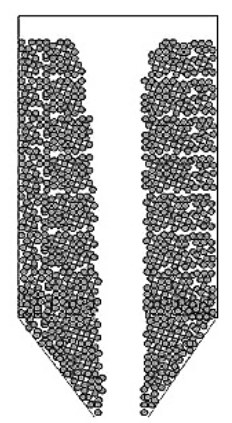

\section{Slika 7 - Zasvođavanje i formiranje cjevaste rupe}

Ovi problemi se redovito pojavljuju u silosima s dimnjačkim načinom pražnjenja, u kojemu se dio materijala giba dok ostatak ostaje stacionaran. Nepravilan protok može imati mnoge mane, uključujući:

- ograničeni vijek trajanja

- segregacija finih čestica ili prašine

- nedovoljno iskorištena oprema ili proces

- nepravilan ili zaustavljen protok

- poplavljivanje ili ispiranje praškastih tvari

- vibracije konstrukcije, podrhtavanje

- neuspjele isporuke materijala ili odgode istih

- stvrdnjavanje, nagomilavanje, gubitak materijala. 


\section{Svojstva protoka materijala}

Većina normi za projektiranje silosa sadrži tablicu svojstava raznih sipkih materijala. Te podatke treba koristiti s oprezom. Treba izbjegavati interpoliranje svojstava ili nagađanje vrijednosti određenog svojstva na temelju sličnosti u opisu materijala.

Ispitivanja svojstava protoka materijala trebala bi se raditi kada je god moguće da bi se precizno izmjerila svojstva protoka i raspon svojstava rasutog materijala koji se skladišti (na primjer, težina željezne rude kreće se u rasponu od 19 do $22 \mathrm{kN} / \mathrm{m}^{3}$ ). To je posebno važno kada materijal nije slobodno-gibajući ili kada su njegova svojstva protoka nepoznata, neizvjesna ili promjenjiva. Uobičajeno se ispituju sljedeća svojstva [1]:

- Funkcija protoka $i$ efektivni kut unutarnjeg trenja: ispitivanje treba izvršiti za sitnozrnate materijale. Koncentracija finih zrna je kod ovih materijala neizbježna zbog segregacije. Kada izmjerimo ove parametre, moguće je izračunati minimalne dimenzije otvora ispusta da bi se izbjegao nepravilan protok.

- Gustoća rasutog materijala: mjeri se uglavnom slijeganje materijala pod različitim pritiscima i izmjerom gustoće pri tim slijeganjima.

- Kut trenja stijenke: bitno je ispitati obje stijenke, cilindra i lijevka. Što je stijenka glađa, veći pritisak djeluje na nju.

- Omjer bočnog tlaka (omjer srednjeg horizontalnog tlaka i srednjeg vertikalnog tlaka): potrebno ga je odrediti pri skladišnoj gustoći čestica i pri razini naprezanja koja odgovara položaju uskladištene sipke tvari u silosu na mjestu gdje se javlja najveće vertikalno naprezanje nakon punjenja.

- Kohezija i kut unutarnjeg trenja

- Abrazivno habanje: predviđa se životni vijek stijenki silosa zbog klizanja materijala duž njih.

Potrebno je napomenuti da svaki od ovih parametara može varirati unutar istog materijala ako se jedan ili više sljedećih uvjeta promijene:

- količina vlage

- vrijeme skladištenja u mirovanju

- raspodjela veličine zrna

- temperatura

- kemijske promjene.

\section{Numerički primjer i analiza tlakova pri različitoj geometriji silosa}

\subsection{Postavke za numeričku analizu}

Izvršena je numerička analiza na tri različite geometrije silosa, tablica 1, u visokospecijaliziranom programu SILOSTRESS TOOL [13]. Ulazni parametri koji su jednaki za sve tri verzije silosa su:

- kapacitet silosa: $\approx 300 \mathrm{~m}^{3}$

- uskladišteni materijal: željezna ruda

- promjer silosa: $d_{c}=6,0 m$

- promjer otvora ispusta: $d=1,8 \mathrm{~m}$.

Tablica 1 - Geometrijski parametri i klasifikacija silosa s obzirom na vitkost

\begin{tabular}{|c|c|c|c|c|c|c|c|}
\hline $\begin{array}{c}\text { Varijanta } \\
\text { silosa }\end{array}$ & $\begin{array}{c}\text { Nagib lijevka } \\
\text { od vertikale }\end{array}$ & $\mathbf{h}_{\mathbf{c}}(\mathbf{m})$ & $\mathbf{d}_{\mathbf{c}}(\mathbf{m})$ & $\mathbf{h}_{\mathbf{c}} / \mathbf{d}_{\mathbf{c}}$ & $\begin{array}{c}\text { Kapacitet } \\
\left(\mathbf{m}^{3}\right)\end{array}$ & $\begin{array}{c}\text { Masa pohranjenje } \\
\text { tvari }(\mathbf{t})\end{array}$ & Vitkost \\
\hline 1. & $30^{\circ}$ & 9,0 & 6,0 & 1,50 & 302,1 & 574,0 & Srednje vitki \\
\hline 2. & $22,5^{\circ}$ & 8,0 & 6,0 & 1,33 & 292,6 & 556,0 & Srednje vitki \\
\hline 3. & $19^{\circ}$ & 8,0 & 6,0 & 1,33 & 306,1 & 581,6 & Srednje vitki \\
\hline
\end{tabular}


Iz EN 1991-4 [1], dodatka E, očitane su karakteristične vrijednosti za željeznu rudu potrebne za analizu: gornja vrijednost jedinične težine $\gamma_{u}=22 \mathrm{kN} / \mathrm{m}^{3}$, kut rasprostiranja $\phi_{\mathrm{r}}=36^{\circ}$, kut unutarnjeg trenja $\phi_{i}=31^{\circ}$, srednja vrijednost omjera bočnog tlaka $K=0,52$ i koeficijenta trenja stijenke $\mu=0,49$. Uvjet za srednje vitke lijevke, iz EN 1991-4 [1]: $1<h_{c} / d_{c}<2$, pri čemu je $h_{c}$ visina odsječka s vertikalnom stijenkom silosa od prijelaza do istovrijedne površine.

$\mathrm{Na}$ temelju prethodno navedenih parametara, u visokospecijaliziranom programu SILOSTRESS TOOL dobiveni su vertikalni (tangencijalni) i horizontalni (normalni) pritisci.

\subsection{Numerička analiza silosa s lijevkom nagiba $30^{\circ}$}
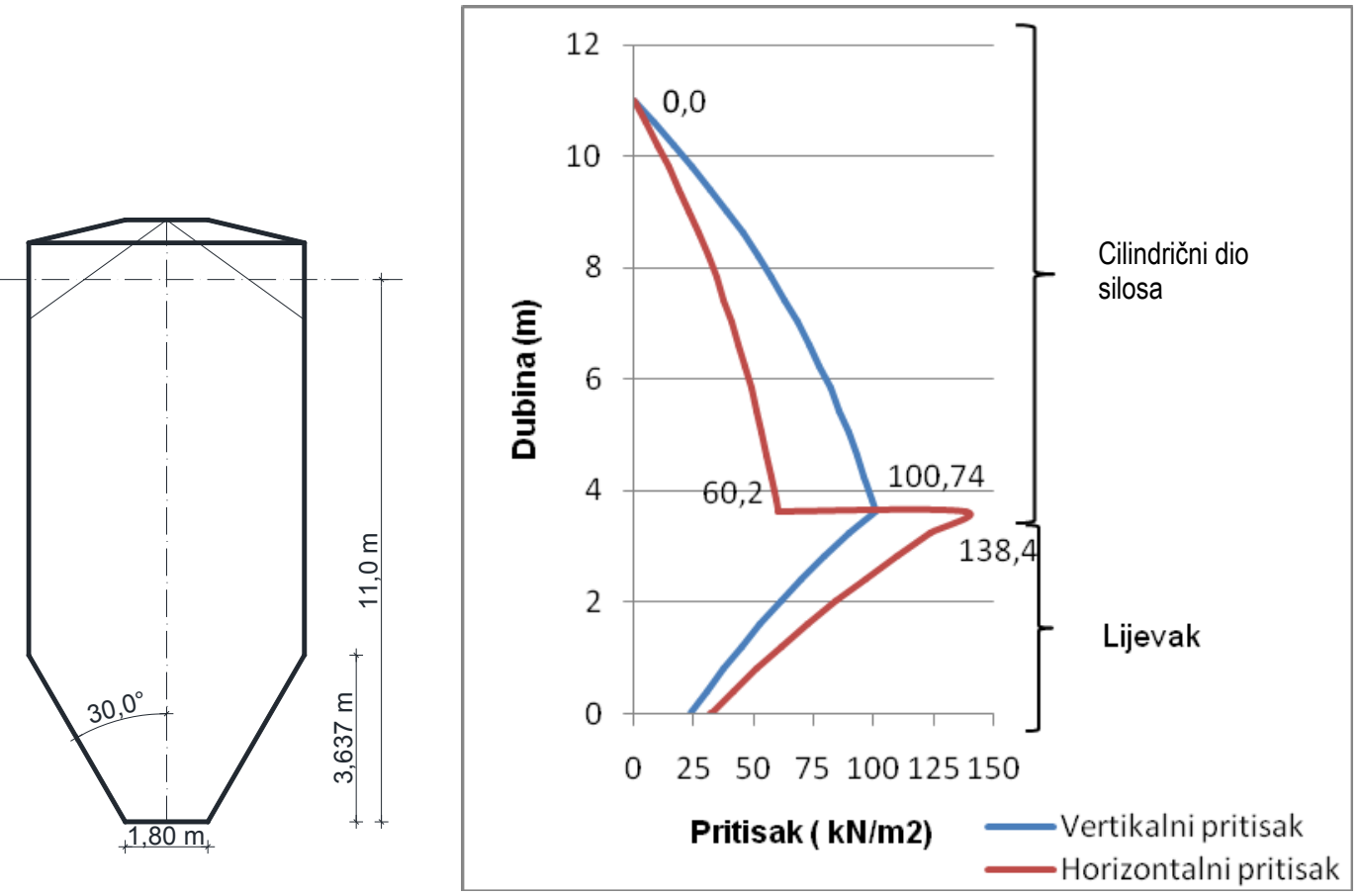

Slika 8 - Dijagrami pritisaka pri pražnjenju i geometrijski prikaz varijante 1. silosa

Na slici 8. prikazana je geometrija silosa koja je služila kao ulazni parametar pri analizi te dijagrami pritisaka kao konačan rezultat. Analizom u SILOSTRESS TOOL-u utvrđeno je da je protok pri ovoj geometriji silosa dimnjački. 


\subsection{Numerička analiza silosa s lijevkom nagiba $22,5^{\circ}$}
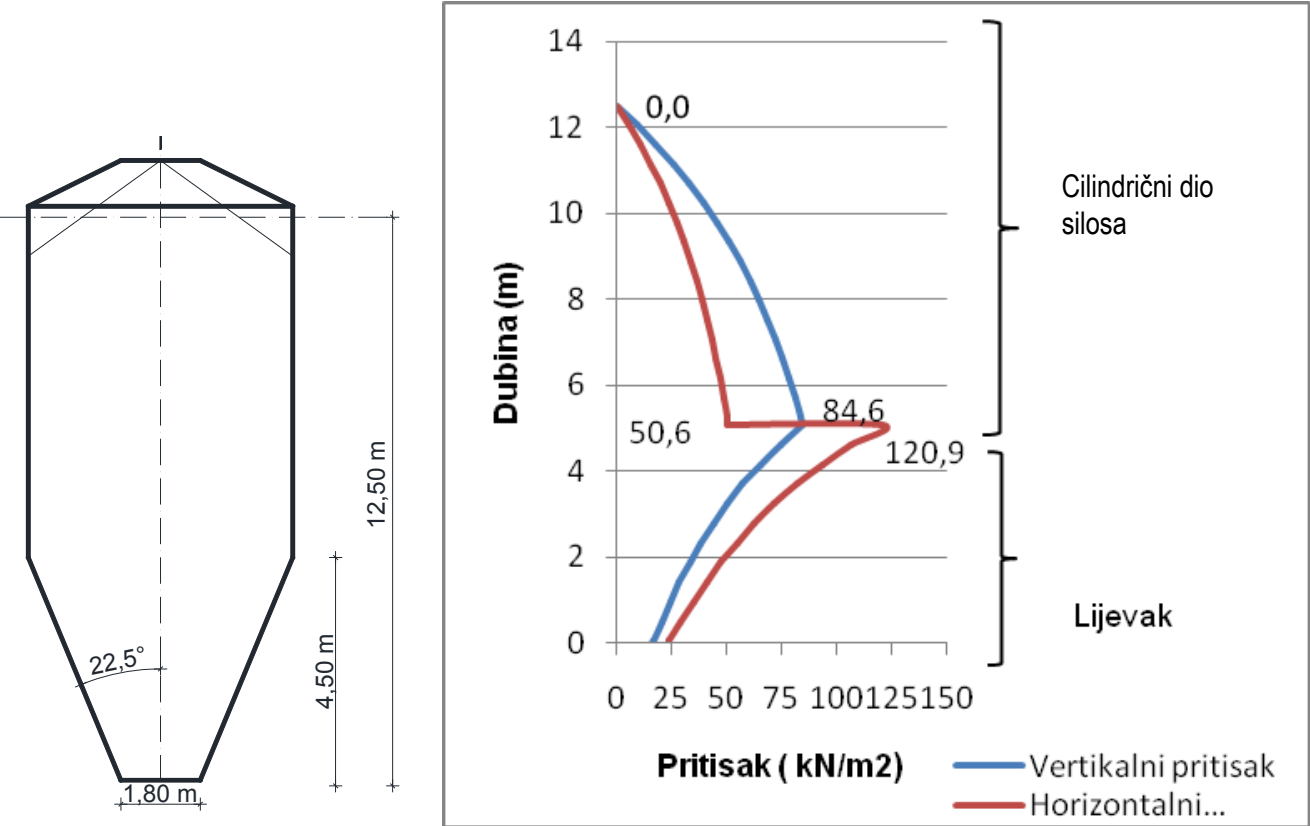

Slika 9 - Dijagrami pritisaka pri pražnjenju i geometrijski prikaz varijante 2. silosa

Na slici 9. prikazana je geometrija silosa koja je služila kao ulazni parametar pri analizi te dijagrami pritisaka kao konačan rezultat. Analizom u SILOSTRESS TOOL-u utvrđeno je da je protok i pri ovoj geometriji silosa dimnjački.

\subsection{Numerička analiza silosa s lijevkom nagiba $19^{\circ}$}
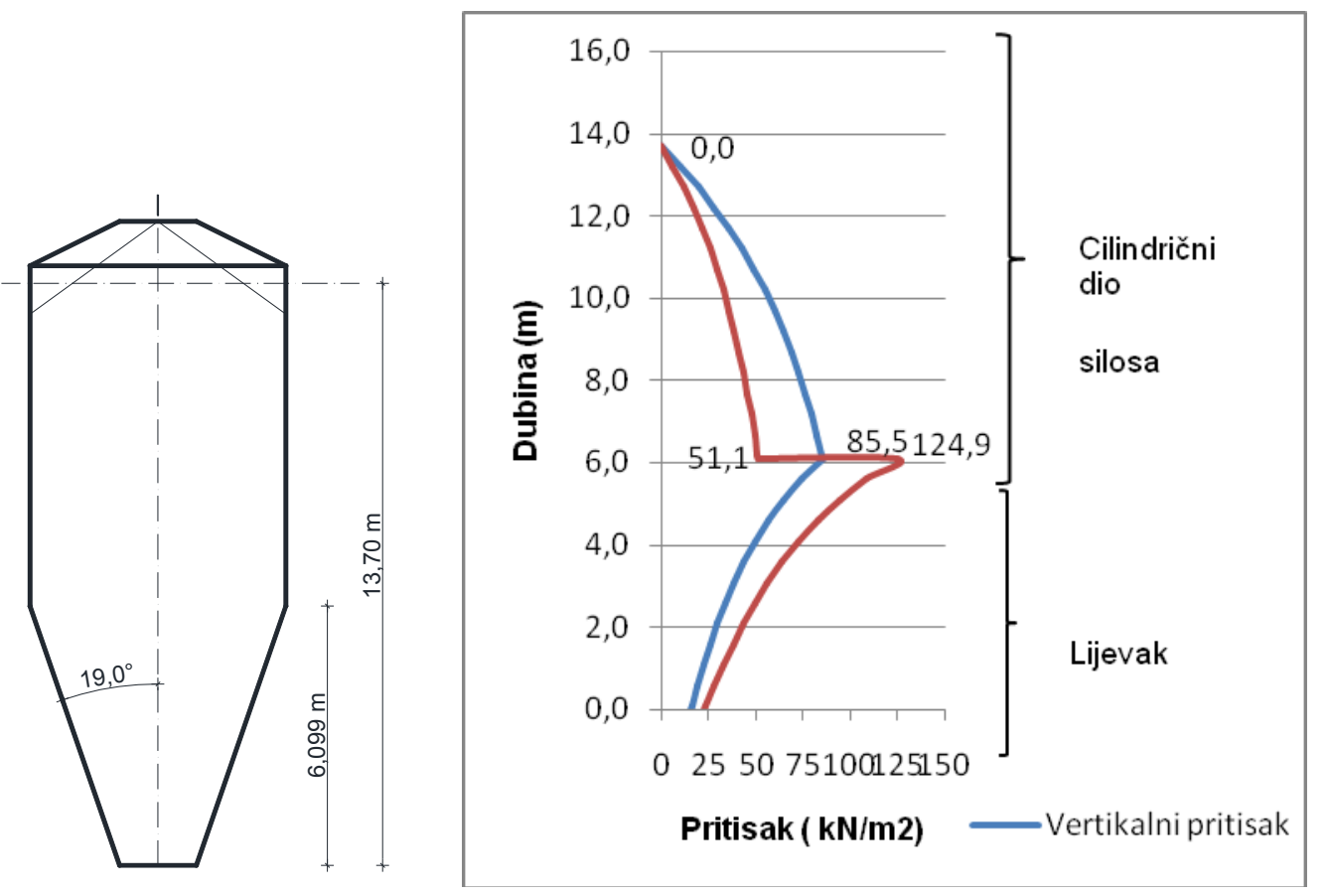

Slika 10 - Dijagrami pritisaka pri pražnjenju i geometrijski prikaz varijante 3. silosa 
$\mathrm{Na}$ slici 10. prikazana je geometrija silosa koja je služila kao ulazni parametar pri analizi te dijagrami pritisaka kao konačan rezultat. Analizom u SILOSTRESS TOOL-u utvrđeno je da je protok pri ovoj geometriji silosa masovni.

\subsection{Usporedba rezultata}

Nakon provedene numeričke analize može se zaključiti da je za masovni protok potreban strmiji nagib lijevka, tablica 2. U prvom slučaju dogodio se dimnjački protok pa su ujedno i pritisci na stijenke najveći. U drugom slučaju protok je i dalje dimnjački, ali se s manjim kutom smanjuju i pritisci na stijenke.

Tablica 2 - Rezultati dobiveni numeričkom analizom

\begin{tabular}{|c|c|c|c|c|}
\hline $\begin{array}{l}\text { Varijanta } \\
\text { silosa }\end{array}$ & $\begin{array}{c}\text { Tangencijalni pritisak } \\
\left(\mathrm{kN} / \mathrm{m}^{2}\right)\end{array}$ & $\begin{array}{l}\text { Normalni pritisak } \\
\qquad\left(\mathrm{kN} / \mathrm{m}^{2}\right)\end{array}$ & $\begin{array}{l}\text { Kapacitet } \\
\qquad\left(\mathrm{m}^{3}\right)\end{array}$ & $\begin{array}{l}\text { Način } \\
\text { protoka }\end{array}$ \\
\hline 1. & 100,7 & 138,5 & 302,1 & dimnjački \\
\hline 2. & 84,6 & 120,9 & 292,6 & dimnjački \\
\hline 3. & 85,5 & 124,9 & 306,1 & masovni \\
\hline
\end{tabular}

Međutim, očigledno je da je u posljednja dva slučaja razlika u kutovima i pritiscima mala, dok istovremeno dolazi do različitog načina protoka. Ovaj rezultat upućuje na činjenicu da se ne može jednostavno sa sigurnošću utvrditi koji će se način protoka dogoditi. Stoga je nužno da preliminarne analize silosa obuhvate ovu problematiku kako bi na vrijeme načinili ciljani izbor načina pražnjenja, a time u konačnici utjecali da ostali postupci tijekom projektiranja silosa budu utemeljeni i svrsishodni.

\section{Zaključak}

Projektiranje konstrukcije silosa je zahtjevan posao i nije ga moguće odraditi po 'šabloni'. Postoji veliki broj parametara koje je potrebno uzeti u obzir, a pogreške pri projektiranju nerijetko za posljedicu imaju kolaps konstrukcije. Jedan od mogućih razloga kolapsa silosa je pogrešno procijenjen način protoka pri pražnjenju silosa. Europske, odnosno danas i hrvatske norme daju smjernice za procjenu načina protoka i način proračuna s obzirom na način protoka. Međutim, te smjernice se ne bi trebale koristiti za funkcionalno oblikovanje silosa jer su općenite i ne uzimaju u obzir sve potrebne parametre.

Projektant bez detaljnih preliminarnih analiza, koje podrazumijevaju dobro poznavanje ponašanja konstrukcije silosa i ponašanja samog uskladištenog materijala, ne može kvalitetno projektirati konstrukciju silosa. Da je problematika složena, svjedoče katastrofalne posljedice koje se događaju prilikom kolapsa silosa. Stoga, za praktične svrhe, normu treba shvatiti kao zbir nužnih uvjeta koje treba zadovoljiti, a dodatnom edukacijom i specijalizacijom postići optimum kod projektiranja ovakvih složenih konstrukcija silosa. Ovaj rad obrađuje samo jedan mali dio navedene problematike koji je nužan za razumijevanje procjene i učinaka načina pražnjenja uskladištenog materijala kod projektiranja silosa.

\section{Literatura}

[1] European Committee for Standardization (CEN) 2006. EN 1991-4: Eurocode 1 - Actions on structures - Part 4: Silos and tanks.

[2] European Committee for Standardization (CEN) 2007. EN 1993-4-1: Eurocode 3: Design of steel structures - Part 4-1: Silos.

[3] European Committee for Standardization (CEN) 2007. EN 1993-1-6: Eurocode 3: Design of steel structures - Part 1-6: Strength and stability of shell structures. 
[4] Chase, G. 2004. Solids Notes, The University of Akron.

[5] Bolanča, M. 2013. Projekt cilindričnog konusnog silosa za skladištenje željezne rude, Diplomski rad, Građevinski fakultet, Sveučilište u Zagrebu,voditelj: Skejić, D.

[6] Sadowski, A.J.; Rotter, J.M. 2011. Steel silos with different aspect ratios: I-Behaviour under concentric discharge, Journal of Constructional Steel Research 67, pp 1537-1544

[7] Sadowski, A.J.; Rotter, J.M. 2011. Steel silos with different aspect ratios: II-Behaviour under eccentric discharge, Journal of Constructional Steel Research 67, pp 1545-1553

[8] Jenike\&Johanson - Bulk Material Engineering. Home Page, <http://www.jenike.com/> [pristupljeno 25.10.2013]

[9] Jacob, K.2010. Bin and Hopper Design, The Dow Chemical Company, Solids Processing Lab.

[10] Carson, J. W.; Jenkyn, R.T.1993., Load Development and Structural Considerations in Silo Design, Reliable Flow of Particulate Solids II, Oslo, Norway

[11] Schulze, D. 2007. Powders and Bulk Solids: Behavior, Characterization, Storage and Flow, Berlin, Heidelberg, New York: Springer

[12] Carson, J.W. 2000.Silo Failures: Case Histories and Lessons Learned, Third Israeli Conference for Conveying and Handling of Particulate Solids, Dead Sea, Israel

[13] Schulze, D. 2011. Software zum Herunterladen: Silo Stress Tool. Home Page <http://www.dietmarschulze.de/> [pristupljeno 5.11.2013] 